\title{
Nabi Idris dalam Kajian Sejarah IImu Falak
}

\author{
Lutfi Nur Fadhilah \& Muhammad al-Farabi \\ Putra* \\ Universitas Islam Negeri Walisongo Semarang \\ Email: lutfinurfadhilah@gmail.com
}

\begin{abstract}
The science of astronomy developed, starting from the pre-Islamic phase (Babylon, Ancient Egypt, Mesopotamia, China, India, France, and Greece) and then penetrated into the Islamic phase. Celestial science has been known since the Babylonians (ancient Iraq) by observing the constellations. Prophet Idris was the prophet who first studied arithmetic based in the book al-Bidāyah. Some literature such as the book al-Khulāșah al-Wafiyyah by KH. Zubair Umar al-Jailany and Mukhtașar Mahāżab by Sheikh Muhammad Yasin al-Fadani stated that Wadi' the science of astronomy was Prophet Idris as. The Sabāik al-żahāb fì Ma'rifat al-Qabāil al-'Arab by al-Suwaidi mentions that the Unusy Prophet was the inventor of astronomy, while the Prophet Idris was the inventor of the science of astrology.
\end{abstract}

Keywords: Astrology, Astronomy, Unusy, Idris

\begin{abstract}
Abstrak
Ilmu falak mengalami perkembangan yaitu mulai dari fase pra Islam (Babilonia, Mesir Kuno, Mesopotamia, Cina, India, Prancis, dan Yunani) kemudian merambah ke dalam fase Islam. Ilmu falak sudah dikenal sejak bangsa Babilonia (Irak kuno) dengan mengamati rasi-rasi bintang. Nabi Idris adalah nabi yang pertama kali mengkaji ilmu hitung berdasarkan kitab al-bidāyah. Studi ini merupakan literatur
\end{abstract}

* PascaSarjana UIN Walisongo Semarang. 
Nabi Idris dalam Kajian .... 116

analisis yang berdasar kepada kajian kitab-kitab karya ulama klasik. Beberapa literatur seperti kitab al-khulāṣah al-wafiyyah karya KH. Zubair Umar al-Jailany dan mukhtașar mahāżab karya Syekh Muhammad Yasin al-Fadani menyatakan bahwa wadi i ilmu falak adalah Nabi Idris as. Kitab sabāik al-żahāb fì ma'rifat al-qabāil al-'arab karya al-Suwaidi menyebutkan bahwa Nabi Unusy adalah penemu ilmu falak, sedangkan Nabi Idris adalah penemu ilmu astrologi.

Kata Kunci: Astrologi, Astronomi, Idris, Unusy

\section{Pendahuluan}

U
ilmurut $\mathrm{KH}$. Zubair Umar al-Jailany, penemu pertama
memberikan ilmu hikmah kepadanya dengan jalan memberikan pengetahuan tentang rahasia-rahasia peredaran bintang dan susunan titik perkumpulan bintang-bintang di jagad raya. ${ }^{1}$ Pernyataan ini menunjukkan bahwa ilmu falak sudah barang tentu telah ada pada masa itu atau bahkan sebelum Nabi Idris as.

Pembahasan ilmu falak yang memiliki kecenderungan perihal persoalan ibadah tidaklah merupakan suatu problematika, akan tetapi ilmu falak yang telah ada sebelum Islam ini apakah juga membahas persoalan ibadah umat Islam atau lebih luas cakupannya mengingat Nabi Idrislah yang dinobatkan sebagai penemu ilmu falak walaupun masih perlu adanya penelitian. Ilmu falak memiliki manfaat yang sangat banyak bagi manusia. Namun, apakah kita pernah berpikir untuk melacak siapakah sesungguhnya penemu pertama ilmu falak hingga sekarang masih bisa dirasakan manfaatnya yang teramat penting ini. Apakah Nabi Idris ahli astronomi ataukah astrologi atau kedua-duanya? Ini merupakan masalah pemahaman teks makna sesuai dengan yang memaknai.

${ }^{1}$ Zubair Umar al-Jailany, al-Khulāṣah al-Wafiyyah, (Kudus: Menara Kudus, tt), h. 5 . 
117 Lutfi Nur Fadhilah \& Muhammad al-Farabi Putra

Astronomi dan astrologi dahulu merupakan kesatuan ilmu, akan tetapi seiring berjalannya waktu keduanya dipisah menjadi disiplin ilmu masing-masing.

\section{Ilmu Falak dalam Lintas Sejarah}

Ilmu falak selama ini dikenal dengan ilmu pengetahuan eksak yang objek kajiannya adalah Bumi, Bulan, Matahari dan benda-benda langit lainnya. Kajian-kajian yang ada di dalamnya termasuk theoritical astronomy atau ilmu falak 'ilmy. Penyempitan ruang lingkup pembahasan yang ada di dalam ilmu falak berupa perhitungan awal waktu salat, menghitung azimuth kiblat, menghitung awal bulan kamariah, dan menghitung kapan terjadinya gerhana adalah kajian terkait ibadah-ibadah tertentu dalam ajaran agama Islam.

Empat kajian ilmu falak di atas termasuk practical astronomy/ observational astronomy atau ilmu falak 'amaly. Ilmu falak banyak dinamai dengan berbagai nama, antara lain:

1. Ilmu falak, dinamai ilmu falak karena falak berarti orbit atau lintasan benda-benda langit (مدار النجوم). Muhammad Abdul Karim menyatakan: ilmu falak adalah ilmu yang khusus membahas perhitungan pergerakan Matahari, Bulan, planet, dan bintang. Ilmu falak juga menentukan posisi bintang dan mempelajari karakteristiknya serta menafsirkan peristiwa alam dengan tafsiran atau penjelasan ilmiah.

2. Ilmu hisab, artinya menghitung.

3. Ilmu rașd, yang artinya mengamati. Masyarakat dahulu yang terkenal dalam pengamatan benda-benda langit adalah mereka yang tinggal di daerah Mesopotamia (daerah antara sungai Eufrat dan Tigris) seperti bangsa 
Nabi Idris dalam Kajian .... 118

Babylonia dan Assyria. Mereka meninggalkan catatan astronomi dari sekitar $3000 \mathrm{SM} .^{2}$

Ilmu falak memiliki berberapa cabang ilmu yang dengannya kita bisa menyimpulkan bahwa ilmu falak pada masa kejayaan Islam sama seperti ilmu astronomi pada saat sekarang ini, bahkan lebih luas lagi cakupannya. Meteorologi, klimatologi, geofisika, geografi, navigasi, dan pelayaran termasuk ke dalam satu induk ilmu, yaitu ilmu falak. Ilmu falak Arab dan Islam yang disebut-sebut oleh orang Arab dan cendekiawan muslim pada masa dinasti Abbasiyah di bidang ilmu falak adalah berupa kajian-kajian dan pembahasan yang lebih luas karena mencapai masa kejayaan ilmu pengetahuan. Di antara pembahasannya adalah tentang dasar-dasar ilmu haiah, sistem penanggalan bangsa-bangsa terdahulu, hisab segitiga bola, lingkaran bola langit dan tata koordinatnya, irtifä' al-syams, bujur dan lintang suatu daerah, jarak titik pusat bumi ke permukaan suatu daerah, jarak antara dua tempat, arah kiblat, pergerakan Matahari dan bulan, parallax, konjungsi Matahari dan bulan, gerhana, hisab rukyah hilal, hisab manzilah qamar, manzilah bintang-bintang, pergerakan planet, dan sebagainya. Obyek kajiannya tentang perhitungan bintang-bintang dan kedudukannya di langit. Adapun pembahasan yang lain adalah tentang ilmu nujum dan proses penciptaan alam semesta. ${ }^{3} \mathrm{Al}-$ Battani mengatakan bahwa apa yang diperoleh dari ilmu falak merupakan anugerah penalaran dan pemikiran. Ilmu falak dapat menjadi media untuk menetapkan tauhid kepada Allah SWT, mengetahui keagungan-Nya, kebesaran dan keluasan hikmah-Nya. ${ }^{4}$

2 Yahya Syami, 'Ilmu al-Falak min Șafahat al-Turās al-'Ilmy, (Beirut: Dār al-Kitāb al-'Arabī, cet. 1, 1997), h. 56.

${ }^{3}$ Yahya Syami, 'Ilmu al-Falak ..., h. 47.

${ }^{4}$ Muhammad Ali Ustman, Para Ilmuan Muslim Paling Berpengaruh terhadap Peradaban Dunia, (Yogyakarta: IRCiSoD, cet. 1, 2007), h. 169. 
119 Lutfi Nur Fadhilah \& Muhammad al-Farabi Putra

Menurut bangsa Babilonia, bintang-bintang adalah petunjuk Tuhan yang harus dipecahkan. Mereka menggunakan rasi bintang untuk meramal kehidupan sehari-hari. Ini menunjukkan bahwa ilmu astrologi lebih diminati dan lebih maju, akan tetapi tidak menutup kemungkinan mereka tetap menggunakan ilmu astronomi dalam hal penentuan musim, pergantian hari, bulan, dan penunjukkan arah. Pada masa itu, mereka sudah bisa menentukan kapan terjadinya gerhana Matahari dan Bulan dengan menggunakan rasi bintang. Adanya penyebutan satu jam sama dengan 60 menit, 1 menit sama dengan 60 detik dikenal dengan hukum sittiny atau sudus menurut masyarakat Babilonia. ${ }^{5}$ Menurut riwayat, Nabi Idris diutus ke bangsa Babilonia, maka kemungkinan ada hubungannya antara bangsa Babilonia dengan Nabi Idris mengenai kajian terhadap penemu ilmu falak, karena keduanya sama-sama pada awal munculnya ilmu falak.

\section{Penemu Ilmu Falak dalam Beberapa Versi}

a. KH. Zubaer Umar al-Jaelany menyatakan penemunya adalah Nabi Idris dengan adanya maqālah yang ada di dalam kitab al-khulāṣah al-wafiyyah,

$$
\begin{aligned}
& \text { وو اضعه نبي الله ادريس على نبينا و عليه الصلاة و السلام وهو اول من استخرج الحكمة }
\end{aligned}
$$

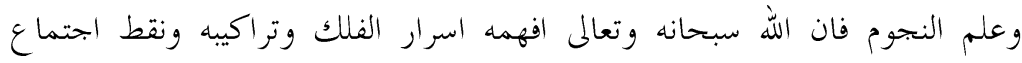

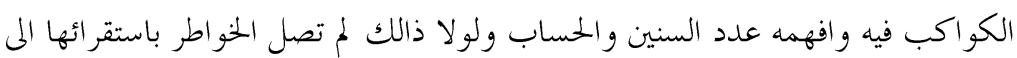

b. Syekh Yasin al-Fadani, yang menyatakan Nabi Idris dan Nabi Adam.

. Adanya pernyataan bahwa Nabi Adam sebagai penemu ilmu falak karena Nabi Adam adalah manusia pertama yang diturunkan ke bumi

${ }^{5}$ Musthofa Bisri, al-Bisri Kamus Indonesia Arab. (Surabaya: Pustaka Progresif, 1999), h. 90. 
Nabi Idris dalam Kajian .... 120

dan menjadi khalifah di muka bumi. Nabi Adam sebagai khalifah pertama di bumi tentu ia dibekali dengan pengetahuan-pengetahuan tentang segala sesuatu, sebagaimana dalam surat al-Baqarah 31-32. Lafaz kullahā di dalamnya bisa bermakna kullun ataukah kulliyatun. Jika kullun maka masih memungkinkan adanya istanayat, sedangkan jika kulliyatun maka mencakup semuanya tanpa istišna'. Menurut surat al-Baqarah, disebutkan bahwa dalam hal ini Nabi Adam hanyalah diberi pengetahuan bukan ilmu, jadi walaupun beliau diberi pengetahuan tentang ilmu falak, akan tetapi hanyalah sebatas $t a^{\prime} r i f$, bukan 'ilm.

c. A E. Roy dan D. Clarke dalam bukunya Astronomy: Principle and Practice mengatakan bahwa kami tidak tahu siapa astronom pertama, akan tetapi kami hanya tahu bahwa ilmu falak atau astronomi berkembang maju pada pertengahan milenium ketiga (3000 SM) di bagian Eropa dan orang-orang China memiliki sekolah astronomi sejak 2000 SM. Di segala masa, sejak pertama kali berkembangnya kecerdasan manusia, telah ada orang yang terpesona pada langit dan terdapat aspek perubahan pada mereka. Sejauh lingkungan budaya, telah memungkinkan mereka mencoba merumuskan kosmologi. Sekarang kita tidak berbeda dengan mereka". ${ }^{6}$ Mereka berdua tidak menyatakan siapa penemu pertama ilmu falak.

d. Dr. Ahsin Sakho Muhammad dan Dr. H. A. Sayuti Anshari Nasution, M.A. dalam Atlas Alquran: Amaākin Aqwām A'lam, menyatakan bahwa Nabi Idris adalah manusia pertama yang mengeluarkan kata-kata hikmah dan ilmu astronomi. ${ }^{7}$

${ }^{6}$ A. E. Roy dan D. Clarke, Astronomy: Principle and Practice, (Adam Hilger: Bristol, 1978), h. 3.

7 Nur Hidayatullah al-Banjary, Penemu Ilmu Falak, (Yogyakarta: Pustaka Ilmu, 2013), h. 110. 
121 Lutfi Nur Fadhilah \& Muhammad al-Farabi Putra

e. Nur Hidayatullah Al-Banjary, penulis buku penemu ilmu falak lebih setuju jika Nabi Idris adalah orang pertama yang mengetahui astrologi, bukan astronomi. ${ }^{8}$

\section{Perdebatan Penemu Ilmu Falak}

Syekh al-Fāḍil wa al-Najrīr al-Kāmil Abu al-Fauz Muhammad Amīn al-Bagdadī atau dikenal dengan sebutan AlSuwaidi dalam kitab sabāik al-żahāb fī ma' rifat al-qabāil al-'arab, ia menyatakan bahwa:

$$
\begin{aligned}
& \text { (انوش) بالنون والشين المعجمة وهو وصي ابيه شيت, فلما توفي ابوه قام بسياسة الملك وتدبيره } \\
& \text { من تحت يديه من رعيته, وهو اول من علم الكتابة وعلم الحساب و الشهور و السنين واول }
\end{aligned}
$$

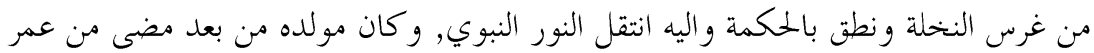

$$
\begin{aligned}
& \text { ابيه شيت ستمائة وخمسة سنين, كما قال ذالك اهل التوراة, وعاش تسعمائة و ستة و ستين } \\
& \text { سنة, و الله اعلم }
\end{aligned}
$$

Unusy adalah pewaris ayahnya yang bernama Syit, anak dari Nabi Syit. Ketika ayahnya wafat, ia menggantikan posisi ayahnya memimpin politik kerajaan dan mengaturnya di bawah pantauannya. Ia adalah orang yang pertama kali mengenal tulisan, ilmu hisab, hisab bulan, dan hisab tahun. ia adalah orang yan pertama kali menanam pohon kelapa dan berbicara dengan hikmah, padanya dialihkan cahaya kenabian. Kelahirannya setelah umur ayahnya melebihi dari 650 tahun sebagaimana dikatakan dalam Taurat. Unusy hidup selama 966 tahun. wallahu a'lam. ${ }^{9}$

Jika dilihat dari maqālah ini, Nabi Unusy adalah penemu pertama ilmu falak berdasarkan pada keterangan bahwa ia orang pertama yang mengenal ilmu hisab, baik hisab bulan maupun hisab Matahari. Ilmu yang membahas tentang bulan dan Matahari tak lain adalah ilmu falak.

\footnotetext{
${ }^{8}$ Nur Hidayatullah al-Banjary, Репети..., h. 112.

${ }^{9}$ Nur Hidayatullah al-Banjary, Репети..., h. 118.
} 
Nabi Idris dalam Kajian .... $\mid 122$

Rahimsyah mengatakan bahwa Akhnukh adalah orang pertama yang pandai membaca, menulis dengan pena, dan berhitung. ${ }^{1}$ Generasi ke tujuh dari Nabi Adam yaltu seorang anak yang bernama Akhnukh bin Yarid bin Mahlail bin Qainan bin Unusy bin Syit bin Adam as. Akhnukh inilah Nabi Idris as yang merupakan satu garis nasab dengan Rasulullah saw. ${ }^{1}$

Al-Suwaidi memaparkan perihal Nabi Idris as dalam kitabnya sebagai berikut:

$$
\begin{aligned}
& \text { (اخنوخ) هو ادريس عليه السلام, ... و كان نبيا وملكا عظيما ويسمى (هرمس) الهرامسة اي } \\
& \text { اسد الاسود واليه انتقل النور النبوي, وانزل الله تعالى عليه ثلاثين صحيفة و نزل عليه وسيه جبرائيل }
\end{aligned}
$$

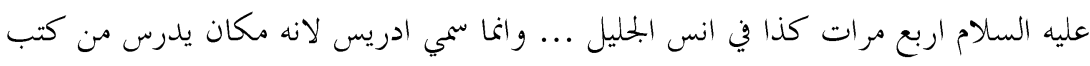

$$
\begin{aligned}
& \text { الاسلام, وهو اول من استخرج الحكمة وعلوم النجوم وعلوم الرياضيات (الطبيعي) و الالهي } \\
& \text { و اسرار الفلك, ولهذا كان سمي (المثلث) لانه نبي و ملك و حكيم, وهو اول من خط بالقلم ... }
\end{aligned}
$$

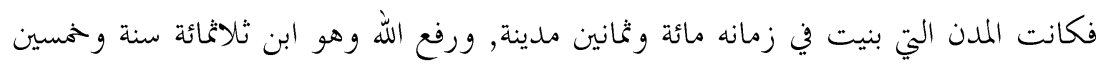

$$
\begin{aligned}
& \text { سنة. }
\end{aligned}
$$

Berdasarkan keterangan di atas, bahwa al-Suwaidi menyatakan bahwa Akhnukh (Nabi Idris as). Ia adalah seorang nabi, raja, dan hakim. Ia disebut sebagai Harmas al-Haramisah atau Asad al-Usud. Adapun ia dinamai Idris karena kegemarannya membaca kitab-kitab terkhusus șuhuf Nabi Adam dan Nabi Syit. Ia adalah orang pertama yang mempopulerkan ilmu hikmah, ilmu nujum, ilmu riyaḍiyat atau matematika, dan rahasia-rahasia falak. Ia juga diberi sebutan muśallaś karena ia nabi sekaligus penguasa yang bijaksana, ia orang pertama yang menulis dengan pena. Ada sekitar 180 kota

1 Rahimsyah dan Ema Wardhana, Kisah Nabi Idris as: Seorang Nabi yang Benar dan Diangkatnya ke Tempat yang Tinggi, (Surabaya: Terbit Terang, 2005), h. 9. Lihat juga Nur Hidayatullah, Pепетu Ilmu Falak, h. 123.

1 Ziedan Maulana, Mutiara Kisah 25 Nabi-Nabi dan ${ }^{1}$ Rasul, (Surabaya: Amelia, 2010), h. 20.

1 Al-Suwaidi, Sabaik al-Zahab fì Ma'rifat Qabā'il al-'Arab, (Beirut: Dar alKutub al-`Ilmiyah, tt). 
123 Lutfi Nur Fadhilah \& Muhammad al-Farabi Putra

yang dibangun pada masa Nabi Idris as. Allah mengangkatnya ketika ia berusia 350 tahun.

Orang Yunani dan Mesir menamai Nabi Idris dengan Hurmus, ada juga yang menamainya TTuṭ. ${ }^{1}$ Dewa Țut berati "pemikiran" dan "waktu" dalam mitologi Mesir Kuno. Ia adalah dewa kebijaksanaan dan sihir. Dewa Tut diyakini sebagai penemu tulisan, astronomi, dan bidang seni lainnya. Biasanya dewa Thoth berkepala burung ibis, kepalanya ada di Khemennu tempat suci. Ia memimpin suatu masyarakat lalu ia berganti nama menjadi Hermopolis oleh orang-orang Yunani. Dewa Țut terkadang juga digambarkan sebagai seorang babon (kera besar). ${ }^{1}$ Dalam kamus munjid dijelaskan bahwa yang dimaksud dengan Ṭuṭ h yaitu "ilāh al-'ulum wa al-ādab fĩ miṣr al-qadīmah. Huwa Hermes al-Yunān. Haikaluhu fī al-asymunain". (Dewa pengetahuan dan peradaban pada masa Mesir kuno. Ia adalah Hermes Yunani). ${ }^{1}$ Tulisan hieroglif dipercaya oleh bangsa Mesir kuno sebagai tulisan yang berasal dari Țut. ${ }^{1}$

Tut inilah yang dimaksud dengan Nabi Idris dalam mitologi Mesir kuno. Huruf hieroglif adalah tulisan pertama yang dikenal dan ditemukan di muka bumi. Tulisan ini muncul pada masyarakat Mesir kuno. Oleh karena itu Nabi Idris dijuluki dengan sebutan Hermes al-Mișry atau Hermes al-Bābily.

Terdapat pernyataan yang menjelaskan bahwa Nabi Idris naik ke garis edar (falak) Zuhal (Saturnus). Ia berkeliling di daerah tersebut selama 30 tahun sebelum ia turun ke bumi, kemudian mengajarkan ilmu perbintangan. Keterangan ini

1 Quraish Shihab, Tafsir..., h. 479.

1 Random House Webster's, College Dictionary, (USA: Random House, 1999), h. 1272.

1 Louis Ma'luf al-Yassu'i, Bernard Tottel al-Yassu'î, Munjid, (Beirut: Dar al-Masyriq, 2002), h. 181.

1 Angelina A. Dan Hapsari, S.T., Pengetahuan tertang Mesir Kuno, (Bandung: Intan Sejati, 2009), h. 14. 
Nabi Idris dalam Kajian .... $\mid 124$

terdapat di rasail/risalah-risalah Ikhwan al-Șofa. ${ }^{1}$ Keluar dari perdebatan bahwa Nabi Idris as atau Hermes dinisbatkan sebagai penemu ilmu perbintangan atau astrologi, bahkan Abu al-Basyar wa al-Anbiya' (Nabi Adam as) juga dinisbatkan sebagai penemu ilmu falak. Mereka mengatakan bahwa Allah sawt menurunkan Adam dan Ia mengajarkan segala sesuatu ilmu kepadanya, termasuk kedokteran dan perbintangan. ${ }^{1}$ Berdasarkan perdebatan di atas, kita dapat memahami bahwa ada yang menyatakan bahwa penemu ilmu falak dinisbatkan kepada Nabi Unusy, Nabi Idris as, dan Nabi Adam as.

\section{Biografi Nabi Idris}

Nabi Idris dikenal dengan sebutan Enoch/Henoch (Penemu). Banyak ilmu-ilmu yang ditemukan oleh Nabi Idris a.s. termasuk menemukan bentuk huruf, tulisan dan alat tulis, pena. Nabi Idris adalah orang pertama yang mengetahui tentang ilmu perbintangan, berhitung, menulis, dan menjahit pakaian. ${ }^{1}$ Ditemukan juga alat jahit dan cała menjahitnya, obat-obatan (medis). Banyak penemuan pada masa Nabi Idris, a.s. karena beliau adalah orang yang suka belajar (pembelajar).

Nabi Idris as dijuluki dengan Harmas alHaramisah (Bahasa Mesir, yang artinya ahli perbintangan atau ahli Astronomi), Hermes (Bahasa Yunani, artinya ahli tafsir (Mufasir)), Drisa atau Driska (Bahasa Aramia, artinya orang yang berpengetahuan tinggi, banyak pengetahuannya, intelektual, terpelajar), Idris (dalam al-Qur'an) berasal dari kata "darasa-yadrusu-darsan", artinya belajar, orangnya disebut Idris.

Nabi Idris (4533-4188 SM) pertama kali diberikan tugas untuk menyampaikan risalah kepada kaumnya. Ia ditugaskna

\footnotetext{
1 Yahya Syami, 'Ilmu..., h. 63.

1 Yahya Syami, 'Ilmu..., h. 64. Lihat juga Nur Hidayåtullah, Penemu..., h. 135.

1 Quraish Shihab, Tafsir..., h. 478.
} 
125 Lutfi Nur Fadhilah \& Muhammad al-Farabi Putra

setelah Nabi Adam dan Nabi Syit. Nabi Idris lahir dan tinggal di Babil, Irak. Ia ditugaskan berdakwah kepada kaumnya yang bernama bani Qabil dan Memphis. Ada juga yang menyebutkan ia lahir di daerah Munaf, Mesir. Nama Nabi Idris disebutkan dalam al-Qur'an sebanyak dua kali. Ia memiliki nama asli Khanukh (Akhnukh). Adapun Idris adalah laqab karena kegemarannya mempelajari mushaf-mushaf Nabi Adam dan Nabi Syit.

Sayyid Quțub menduga bahwa Nabi Idris adalah Uzuris yaitu salah satu tokoh Mesir kuno. Idris menurutnya adalah berdasarkan lidah Arab seperti pelafalan Yahya bagi Yohanes. Uzuris dipercaya sebagai tokoh yang naik ke langit dan hidup di sana. Namun, Sayyid Quțub belumlah memastikan mengenai hal ini walaupun ia tidak menolaknya. ${ }^{2}$

Di dalam Qașaș al-Anbiyā' disebutkan bahwa para ahli berbeda pendapat mengenai lokasi Nabi Idris dilahirkan dan dibesarkan. Sebagian berpendapat, beliau dilahirkan di Mesir, tepatnya di Manaf (Memphis) dan mereka menamakannya dengan Harmas al-Haramisah. Sebagian ahli yang lain berpendapat bahwa beliau dilahirkan dan dibesarkan di Babylon. Dalam bahasa Suryani "Babil" berarti sungai. Nabi Idris lalu memerintahkan seluruh pengikutnya untuk berpindah ke Mesir. Menurut az-Zamakhsyari, kata Idris bukan berasal dari bahasa Arab. Adapun di kisah lain, ia dijuluki harmasu al-haramisah (ahlinya perbintangan) dalam kitab tārikh al-hukamā. Nabi Idris meninggal di langit ke-4 (surga). Allah swt memuji Nabi Idris dengan sifat kenabian dan kebenarannya. ${ }^{2}$ Al-Qur'an menyebut Nabi Idris dalam surat Maryam ayat 56 - 57:

$$
\text { واذكر في الكتاب ادريس انه كان صديقا نبيا (70) ورفعناه مكانا عليا (ov) }
$$

2 Quraish Shihab, Tafsir..., h. 479.

0

2 Imām Abu al-Fidā' al-Ḥāfiz Ibn Kas̀īr al-Damasyqy', Qașaș al-Anbiyā', (Beirut: Dar al-Kutub al-'Ilmiah, 1990), h. 62. 
Nabi Idris dalam Kajian .... 126

“Dan ceritakanlah (hai Muhammad kepada mereka, kisah) Idris (yang tersebut) di dalam al-quran. Sesungguhnya ia adalah seorang yang sangat membenarkan dan seorang nabi. Dan, kami telah mengangkatnya ke martabat yang tinggi."2 (QS. Maryam [19]: 56 - 57).

Firman Allah yang menyatakan bahwa Nabi Idris diangkat ke martabat yang tinggi dalam arti diangkat ke kedudukan yang tinggi. Ulama yang memahaminya dalam arti hakiki yaitu Allah mengangkat Nabi Idris ke langit. Sebagaimana dalam perjanjian lama (Kejadian V: 24) disebutkan bahwa Henokh hidup bergaul dengan Allah lalu ia tidak ada lagi sebab ia telah diangkat oleh Allah. ${ }^{2}$

Nabi Idris adalah salah satu nabi dengan berbagai keistimewaan. Banyak riwayat yang menyatakan bahwa ia adalah nabi yang sangat pintar, orang pertama kali yang menciptakan tulisan dan menemukan alat tulis, pandai menggambar, menjahit, juga ahli dalam bidang astronomi (perbintangan). Ia juga dijuluki sebagai asad al-usud, singa dari segala singa karena keberanian dan kegagahannya. ${ }^{2}$

Dalam beberapa literatur disebutkan bahwa Nabi Idris tidak hanya pandai dan menguasai ilmu astronomi, akan tetapi juga ilmu astrologi. Sejarah adalah fakta yang dimaknai, maka akan menjadi berbeda penafsiran orang satu dengan yang lain sehingga banyak pemaknaan yang didapat. Seperti halnya cerita-cerita israiliyyat yang lebih ke fantasi. Nabi Idris dan Nabi Unusy yang menjadi perdebatan perihal peletak pertama ilmu falak, secara penemuan ilmiah maka Nabi Idrislah yang bisa diakui sebagai penemu ilmu falak yang pertama karena beliau

2 Kementerian Agama, Alquran dan Terjemahannyaa, (Jakarta: Jabal, 2010), h. 309.

2 Quraish Shihab, Tafsir al-Mishbah, (Jakarta: Lentẻra Hati, 2017), h. 479.

2 Dhurorudin Mashad, Mutiara Hikmah Kisah $25^{4}$ Nabi dan Rasul, (Jakarta: Erlangga, 2002), h. 14. 
127 Lutfi Nur Fadhilah \& Muhammad al-Farabi Putra

mencatat dengan pena dan mengajarkan ilmunya kepada umatnya, sedangkan Unusy memang menemukan ilmu falak, akan tetapi ilmu tersebut hanya untuk dirinya sendiri dan tidak diajarkan kepada umatnya.

\section{Bukti Sejarah Nabi Idris sebagai Penemu Ilmu Falak}

Salah satu temuan pada masa Nabi Idris adalah arah utara, yaitu dengan dibuktikan adanya salah satu piramida yang dibangun konon zaman Nabi Idris sisinya mengarah ke arah empat mata angin. Ini menunjukkan bahwa Nabi Idris adalah ahli astronomi, karena pada masa itu kompas belum ditemukan. Ilmu falak dimitoskan bisa meramalkan kapan mati seseorang, sesungguhnya itu sudah terjadi pada masa Nabi Idris yaitu ketika beliau akan dicabut nyawanya oleh Malaikat Izrail.

Nabi Idris rajin mengobservasi bintang dan mengembangkan ilmu astronomi yang kemudian oleh ahli nujum disimpangkan dalam ilmu horoskop dan astrologi, serta banyak dimanfaatkan oleh penyihir-penyihir pada zamannya yang berguru pada Hārut-Mārut. Dikisahkan, Nabi Idris juga bisa menangkap isyarat akan adanya banjir hebat melalui tanda langit. Karena itulah beliau memerintahkan untuk membangun piramid dalam bentuk limas demi melindungi kitab-kitab ilmu. Bangsa Mesir kuno meninggalkan kita catatan-catatan dalam bentuk lukisan yang menceritakan sejarah Mesir sejak 4000-an tahun lalu, segala sesuatu mengenai sejarah mereka, namun tidak ada secuil-pun catatan mengenai piramid Giza. Tiga piramida Giza (salah satunya Khufu) memiliki jarak antarpiramida yang sangat akurat terhadap posisi 3 bintang sabuk Orion (bintang alnitak, almilam, dan mintaka). Akurasi sudut hanya meleset 0,1364 derajat.

Nabi Idris adalah pelopor matematika setidaknya tahun 3000 SM. Ia juga pelopor ilmu astronomi, yaitu penggunaan bintang waluku sebagai penunjuk musim dan rasi bintang orion. Kedua rasi bintang ini digunakan para nelayan atau musafir 
Nabi Idris dalam Kajian .... 128

dahulu sebagai penunjuk jalan. Menurut riwayat Ibnu Kasīir, Nabi Idris adalah orang pertama yang menjahit bajunya sendiri.

\section{Argumentasi Penobatan Nabi Idris sebagai Penemu Ilmu Falak}

Nabi Idris dinobatkan sebagai peletak batu pertama ilmu falak berdasarkan beberapa faktor, yaitu: ${ }^{2}$

1. Nama Nabi Idris disebutkan dalam al-Qur'an sebanyak dua kali. Sedangkan orang Islam senantiasa membaca alQur'an, sedangkan Unusy hanya disebutkan dalam kitab-kitab sejarah yang berkaitan dengan nasab. Adapun Nabi Adam sangat jarang ditemukan yang menyatakan bahwa ia penemu ilmu falak.

2. Nabi Idris adalah pencetus pertama astrologi. Ia juga mengajarkannya kepada umatnya. Unusy memahami ilmu falak tanpa mengajarkannya kepada banyak orang, sehingga Nabi Idris lebih populer disebut sebagai penemu ilmu falak.

3. Nabi Idris merupakan orang yang pertama-tama menulis dengan pena. Nabi Idris melalui tulisan, ia dapat membuat catatan dan bisa dibaca serta dipahami oleh orang-orang generasi berikutnya. Unusy juga orang pertama menulis namun tidak dengan pena yang menyebabkan tulisannya tidak dikenal oleh banyak orang karena tidak awetnya tulisan tanpa pena.

4. Penobatan Nabi Idris sebagai penemu ilmu astronomi karena ia pernah mengalami pertentangan oleh kaumnya sehingga ia memberikan peringatan kepada mereka dengan adanya malapetaka jika mereka membangkang. Ancaman itu benar terjadi adanya, oleh karena itu peringatan tersebut oleh umatnya disebut sebagai

2 Nur Hidayatullah al-Banjary, Репетu Ilmu Fåak, (Yogyakarta: Pustaka Ilmu, 2013), h. 145. 
ramalan karena menginformasikan hal yang akan datang. Hal ini berkaitan dengan pengetahuan astrologi.

\section{Penutup}

Ilmu falak dalam haiahnya membahas tentang pergerakan bumi, bulan, manzilah qamar, bintang-bintang, pergerakan planet serta kedudukan terbit dan terbenamnya dari bumi. Pembahasan ilmu falak mengenai alam menurut sejarah yang berkembang dan sampai kepada kita adalah dibawa oleh Nabi Idris sebagai pencetus pertamanya. Kitab suci dan mitologi menyatakan bahwa Nabi Idrislah penemu ilmu falak dengan berbagai versi penyebutan atau laqab Nabi Idris as. Salah satu tulisan yang menyatakan bahwa Unusy adalah penemu pertama ilmu falak adalah kitab sabāik al-żahāb fì ma'rifat qabāil al-'arab karya al-Suwaidi. Jika melihat kepada sejarah, Unusy merupakan orang pertama yang mengetahui hal ihwal falak, namun ia tidak mengajarkannya kepada kaumnya. Adapun Nabi Idris ia memahami dan mengajarkan kepada kaumnya sehingga ilmu yang ia miliki dapat terjaga ketersambungannya. Dengan kata lain, Nabi Idrislah yang pertama kali menemukan ilmu falak karena yang sampai kepada kita adalah ilmu yang dahulu tentu diajarkan dari masa ke masa.

Al-Suwaidi dalam karyanya sabāik al-żahāb fī ma'rifat qabāil al-'arab mengatakan bahwa Nabi Unusy adalah penemu ilmu falak, sedangkan Nabi Idris adalah penemu ilmu astrologi. Masa hidup Nabi Idris dengan Nabi Unusy lebih dahulu Nabi Unusy sehingga wajar dikatakan demikian, karena astrologi tidak akan muncul kecuali setelah ilmu astronomi, dalam hal ini adalah ilmu falak. Nabi Unusy adalah keturunan kedua Nabi Adam sedangkan Nabi Idris adalah keturunan ke tujuh dari Nabi Adam as. Selanjutnya, Nabi Idris banyak disebutkan dalam kitab-kitab terdahulu dengan nama-nama yang beragam. 
Nabi Idris dalam Kajian .... 130

\section{Daftar Pustaka}

A. E. Roy dan D. Clarke, Astronomy: Principle and Practice, Adam Hilger: Bristol, 1978.

Aizid, Rizem, Kisah Sejarah Terlengkap 25 Nabi Terkemuka, Yogyakarta: Safirah, 2014.

Al-Azizi, Abdul Syukur, Kitab Peninggalan-Peninggalan Bersejarah Para Nabi, Yogyakarta: Saufa, 2014.

Al-Banjary, Nur Hidayatullah, Penemu Ilmu Falak, Yogyakarta: Pustaka Ilmu, 2013.

Al-Damasyqy, Imām Abu al-Fidā' al-Ḥāiz Ibn Kas̄īr, Qașaṣ alAnbiyā', Beirut: Dar al-Kutub al-'Ilmiah, 1990.

Al-Jailany, Zubair Umar, al-Khulāṣah al-Wafiyyah, Kudus: Menara Kudus, tt.

Al-Najār, 'Abdul Wahhāb, Qașaṣ al-Anbiyā', Beirut: Dar al-Kutub al-'Ilmiah, tt.

Al-Naisābury, Abī Ishāa Ahmad ibn Muhammad ibn Ibrāhīm, Qașaș al-Anbiyā' al-Muśamma 'Arāis al-Majālis, Beirut: Dar al-Kutub al-'Ilmiyah, 1994.

Al-Shabuni, Muhammad Ali, Kenabian dan Para Nabi, Surabaya: PT Bina Ilmu, 1993.

Al-Suwaidi, Sabaik al-Zahab fī Ma'rifat Qabā'il al-'Arab, Beirut: Dar al-Kutub al-'Ilmiyah, tt.

Al-Yassu'i, Louis Ma'luf, Bernard Tottel al-Yassu'i, Munjid, Beirut: Dar al-Masyriq, 2002.

Angelina A. dan Hapsari, S.T., Pengetahuan tentang Mesir Kuno, Bandung: Intan Sejati, 2009.

Bisri, Musthofa, al-Bisri Kamus Indonesia Arab, Surabaya: Pustaka Progresif, 1999.

Izzuddin, Ahmad, Laporan Penelitian Individual, Melacak Pemikiran Hisab Rukyah Syekh Yasin al-Fadani (Studi atas Kitab al-Mukhtashar al-Mahadzab), Semarang: IAIN Walisongo, 2009.

Mashad, Dhurorudin, Mutiara Hikmah Kisah 25 Nabi dan Rasul, Jakarta: Erlangga, 2002. 
131 Lutfi Nur Fadhilah \& Muhammad al-Farabi Putra

Maulana, Ziedan, Mutiara Kisah 25 Nabi-Nabi dan Rasul, Surabaya: Amelia, 2010.

Mujtahid, Umar, Kisah Para Nabi, Jakarta: Ummul Qura, 2013.

Rahimsyah dan Ema Wardhana, Kisah Nabi Idris as: Seorang Nabi yang Benar dan Diangkatnya ke Tempat yang Tinggi, Surabaya: Terbit Terang, 2005.

Random House Webster's, College Dictionary, USA: Random House, 1999.

Shihab, M. Quraish, Tafsir al-Mishbah, Jakarta: Lentera Hati, 2017.

Syami, Yahya, 'Ilmu al-Falak min Safahat al-Turās al-'Ilmy, Beirut: Dar al-Kitāb al-'Arabī, cet. 1, 1997.

Ustman, Muhammad Ali, Para Ilmuan Muslim Paling Berpengaruh terhadap Peradaban Dunia, Yogyakarta: IRCiSoD, cet. 1, 2007. 